\title{
Hubungan Pola Asuh Ibu dengan Perilaku pada Anak Sekolah Dasar
}

\author{
Nurul Istiqomah, Retno Sutomo, ${ }^{*}$ Sri Hartini** \\ Magister Keperawatan, *Departemen Ilmu Kesehatan Anak Fakultas Kedokteran, ${ }^{* *}$ Departemen Magister Keperawatan Universitas \\ Gadjah Mada Yogyakarta
}

Latar belakang. Anak usia sekolah dengan masalah perilaku akan memperlihatkan kerusakan keterampilan sosial dan mengalami penolakan dari teman sebayanya. Pola asuh yang diberikan oleh orang tua kepada anak juga akan memengaruhi kepribadian anak. Anak akan sulit bersosialisasi dan berkembang apabila terdapat kesalahan pola asuhorang tua.

Tujuan. Mengetahui hubungan antara pola asuh Ibu dengan perilaku pada anak sekolah dasar.

Metode. Penelitian ini menggunakan rancangan studi cross-sectional. Penelitian ini dilakukan pada bulan Mei-Juni 2018. Subjek penelitian berjumlah 110 bu dari anak SD yang telah memenuhi kriteria inklusi dan eksklusi yang dipilih secara multistage cluster random sampling. Instrumen yang digunakan adalah kuesioner pola asuh orang tua, Strength and Difficulties Questionnaire (SDQ), Brief Family Relationship Scale (BFRS), dan kuesioner demografi. Analisis data bivariat dengan Chi-square atau Fisher's dan dilanjutkan dengan Coefficient Contingency.

Hasil. Anak yang mengalami masalah perilaku secara keseluruhan sebesar 43,7\%. Pola asuh demokratis merupakan pola asuh terbanyak yang diterapkan oleh ibu $(78,2 \%)$. Terdapat hubungan antara pola asuh ibu dengan perilaku anak $(\mathrm{p}<0,05)$.

Kesimpulan. Terdapat hubungan antara pola asuh ibu dengan perilaku anak SD. Peneliti selanjutnya diharapkan meneliti pola asuh dan perilaku anak tidak hanya menggunakan laporan ibu saja, tetapi menggunakaan metode observasi serta melibatkan lebih dari satu informan. Sari Pediatri 2020;21(5):302-9

Kata kunci: anak usia sekolah dasar, pola asuh ibu, perilaku

\section{Relationship of Maternal Parenting Style and Behavior in Elementary School Children}

Nurul Istiqomah, Sri Hartini, ${ }^{*}$ Retno Sutomo**

Background. School-age children with behavioral problems will show damage to social skills and experience rejection from their peers. The parenting style used by parents to children will also affect child's personality. Children will be difficult to socialize and develop if there are errors in parenting style used by parents to their children.

Objective. To observe relationship between maternal parenting style with behavior of elementary school children.

Method. This study used a cross-sectional study design. Research was conducted in May-June 2018. Subjects were 110 mothers of elementary school children who had fulfilled the inclusion and exclusion criteria, selected by multistage cluster random sampling. The instruments used were parenting questionnaire, Strength and Difficulties Questionnaire (SDQ), Brief Family Relationship Scale (BFRS) and demographic questionnaire. Bivariate data analysis was done using Chi-square or Fisher's and continued with Coefficient Contingency.

Result. Children who experience overall behavioral problems are 43.7\%. Democratic parenting is the most parenting style applied by mother $(78.2 \%)$. There is a relationship between maternal parenting style with child behavior $(\mathrm{p}<0.05)$. There is no relationship between child gender, parent and child closeness with behavior of elementary school children.

Conclussion. There is a relationship between maternal parenting style and behavior of elementary school children. Researchers are expected to examine parenting style and children's behavior not only based on the mother's report but using observation method and involving more than one informant. Sari Pediatri 2020;21(5):302-9

Keywords: elementary school children, maternal parenting style, behavior

Alamat korespondensi: Nurul Istiqomah. Magister Keperawatan Fakultas Kedokteran Kesehatan Masyarakat dan Keperawatan Universitas Gadjah Mada, Jl. Farmako, Sekip, Yogyakarta 55281. Email: nurulistiqomahh207@gmail.com 
M asalah perilaku dapat terjadi pada berbagai usia anak, termasuk pada usia pertengahan atau usia sekolah dasar. ${ }^{1}$ Seiring bertambah usia maka masalah perilaku akan semakin berkurang. Namun, apabila tetap dialami pada masa anak maka akan mengakibatkan ketidakmampuan menyesuaikan diri. ${ }^{2}$ Ketidakmampuan menyesuaikan diri yang dimaksud adalah adanya penolakan dari teman sebaya, masalah conduct dan perilaku antisosial pada masa remaja nantinya. ${ }^{3}$ Masalah perilaku pada anak sekolah dasar (SD) di Kabupaten Sleman Yogyakarta berdasarkan penelitian sebelumnya, terdapat 33 (20,5\%) dari 161 anak sekolah dasar terdiagnosis gangguan tingkah laku. ${ }^{4}$

Pola asuh yang diberikan oleh orang tua kepada anak juga akan memengaruhi kepribadian anak. Anak akan sulit bersosialisasi dan berkembang apabila terdapat kesalahan dalam pola asuhorang tua. ${ }^{5}$ Tipe pola asuh terdiri dari demokratis, permisif, dan otoriter. ${ }^{6}$ Sebuah penelitian metaanalisis menyatakan bahwa pola asuh orang tua yang cenderung permisif (kurang memperhatikan, kurang memberikan supervisi pada anak) menjadi pengaruh besar terhadap masalah perilaku pada anak. ${ }^{7}$

Hubungan primer dengan pengasuh mengakibatkan hasil perkembangan tidak optimal, seperti masalah perilaku. Masalah perilaku tersebut, seperti agresi, pertemanan yang tidak sehat, hiperaktivitas, dan masalah dengan teman sebaya. Pola asuh orang tua juga memengaruhi bagaimana perilaku prososial. ${ }^{8}$ Penelitian terkait pola asuh orang tua dilakukan di Kecamatan Cangkringan Kabupaten Sleman melaporkan bahwa dari 92 subjek terdapat $46,7 \%$ memiliki pola asuh permisif dan $45,7 \%$ memiliki pola asuh otoriter. ${ }^{9}$ Tujuan penelitian ini adalah mengetahui hubungan pola asuh ibu dengan perilaku pada anak sekolah dasar (SD).

\section{Metode}

Penelitian dengan desain cross sectional dilakukan di Sekolah Dasar (SD) di Kabupaten Sleman (Mei-Juni 2018). Populasi penelitian adalah ibu yang memiliki anak SD di Kabupaten Sleman. Kriteria inklusi adalah ibu yang merawat dan tinggal satu rumah dengan anaknya dan bersedia ikut penelitian. Subjek diekslusi apabila ibu mengalami gangguan mental, dan ibu yang memiliki anak dengan gangguan perkembangan autism spectrum disorder/ASD dan intelectual disability/DI. Digunakan 3 kuesioner, yakni kuesioner pola asuh orang tua untuk melihat pola asuh ibu. ${ }^{10}$ Strength and difficulties questionnaire (SDQ) ${ }^{11}$ untuk mengetahui perilaku anak, dan untuk variabel luar menggunakan brief family relationship scale $(\mathrm{BFRS})^{12}$ untuk mengetahui kedekatan orangtua dengan anak dan jenis kelamin menggunakan kuesioner demografi. Besar sampel dihitung dengan rumus perkiraan sampel untuk estimasi proporsi suatu populasi. ${ }^{13}$ Tingkat kepercayaan 1,96 pada $\alpha$ 0,05, proporsi prevalensi masalah perilaku $20,5 \%,{ }^{4}$ derajat ketepatan yang digunakan sebesar $10 \%$. Jumlah subjek yang didapatkan berdasarkan perhitungan adalah 110 ibu. Teknik sampling yang digunakan dalam penelitian ini adalah multistage cluster random sampling. Guru wali kelas untuk mengonfirmasi terkait pertemanan dengan teman sebaya.

Peneliti mengadakan pertemuan dengan ibu dan dibantu oleh 2 orang asisten penelitian Tempat penelitian adalah di masing-masing SD yang digunakan dalam penelitian ini. SD yang mewakili adalah SDN Adisucipto 1, SD Muhammadiyah Kayen, SDN Nanggulan, SDN Karangasem, SDN Gejayan. Dilakukan pengisian kuesioner oleh ibu dan guru wali kelas anak SD. Pengolahan data dengan SPSS 20.0, kemudian dilakukan analisis data dengan chi square atau Fisher's dan dilanjutkan dengan Coefficient contingency. Penelitian ini telah mendapatkan persetujuan dari Komite Etik FK Kedokteran Universitas Gadjah Mada.

\section{Hasil}

Karakteristik dasar subjek penelitian, kedekatan orangtua dan anak, pola asuh ibu, dan perilaku anak tertera pada Tabel 1 . Tingkat pendidikan terakhir ibu terbanyak ada pada tingkat pendidikan tinggi, yakni 47 $(42,7 \%)$. Kedekatan orang tua dan anak menunjukkan bahwa lebih dari setengah ibu menyatakan memiliki hubungan yang baik dengan anaknya.

Tipe pola asuh terbanyak yang diterapkan oleh ibu pada anak usia SD adalah tipe demokratis, yakni 86 $(78,2 \%)$ ibu. Pola asuh non demokratis diterapkan oleh ibu $24(21,8 \%)$. Pola asuh non demokratis terdiri dari pola asuh otoriter yang diterapkan $21(19,1 \%)$ ibu dan pola asuh permisif hanya diterapkan oleh $3(2,7 \%) \mathrm{ibu}$.

Terdapat 2 item pernyataan pola asuh demokratis yang mengambarkan kasih sayang dan pengawasan 
Tabel 1. Karakteristik dasar subjek penelitian $(\mathrm{n}=110)$

\begin{tabular}{|c|c|c|}
\hline Variabel & Frekuensi & $\%$ \\
\hline \multicolumn{3}{|l|}{ Pendidikan terakhir ibu } \\
\hline Sekolah dasar & 4 & 3,6 \\
\hline SMP & 17 & 15,5 \\
\hline SMA & 42 & 38,2 \\
\hline Pendidikan tinggi & 47 & 42,7 \\
\hline \multicolumn{3}{|l|}{ Jenis kelamin anak } \\
\hline Laki-laki & 57 & 51,8 \\
\hline Perempuan & 53 & 48,2 \\
\hline \multicolumn{3}{|l|}{ Tingkat pendidikan anak } \\
\hline Kelas 1 & 24 & 21,8 \\
\hline Kelas 2 & 24 & 21,8 \\
\hline Kelas 3 & 26 & 23,6 \\
\hline Kelas 4 & 19 & 17,3 \\
\hline Kelas 5 & 17 & 15,5 \\
\hline \multicolumn{3}{|c|}{ Lama guru menjadi wali kelas } \\
\hline Satu tahun atau lebih & 25 & 100 \\
\hline Kurang dari 1 tahun & 0 & 0 \\
\hline \multicolumn{3}{|c|}{ Kedekatan orang tua dan anak } \\
\hline Baik & 97 & 88,2 \\
\hline Tidak baik & 13 & 11,8 \\
\hline \multicolumn{3}{|l|}{ Pola asuh ibu } \\
\hline Demokrasi & 86 & 78,2 \\
\hline Otoriter & 21 & 19,1 \\
\hline Permisif & 3 & 2,7 \\
\hline \multicolumn{3}{|l|}{ Perilaku anak SD } \\
\hline \multicolumn{3}{|l|}{ Perilaku keseluruhan } \\
\hline Normal & 63 & 57,3 \\
\hline Abnormal & 47 & 43,7 \\
\hline \multicolumn{3}{|l|}{ Masalah emosional } \\
\hline Normal & 95 & 86,4 \\
\hline Abnormal & 15 & 13,6 \\
\hline \multicolumn{3}{|l|}{ Masalah conduct } \\
\hline Normal & 103 & 93,6 \\
\hline Abnormal & 7 & 6,4 \\
\hline \multicolumn{3}{|l|}{ Hiperaktivitas } \\
\hline Normal & 103 & 93,6 \\
\hline Abnormal & 7 & 6,4 \\
\hline \multicolumn{3}{|c|}{ Hubungan dengan teman sebaya (laporan ibu) } \\
\hline Normal & 105 & 95,5 \\
\hline Abnormal & 5 & 4,5 \\
\hline \multicolumn{3}{|c|}{ Hubungan dengan teman sebaya (laporan guru wali kelas) } \\
\hline Normal & 73 & 66,4 \\
\hline Abnormal & 37 & 33,6 \\
\hline \multicolumn{3}{|l|}{ Perilaku prososial } \\
\hline Normal & 109 & 99,1 \\
\hline Abnormal & 1 & 0,9 \\
\hline
\end{tabular}


dari orangtua yang seimbang. Jawaban sangat setuju oleh ibu, terkait dengan sendau gurau di dalam keluarga sebanyak $52,7 \%$ dan pernyataan terkait dengan pemberian penjelasan terkait dengan suatu tindakan (mengingatkan anak untuk membereskan mainan) yang dilakukan oleh Ibu sebesar 51,8\%. Ibu yang melibatkan anak dalam menyiapkan saat akan makan sbesar 43,6\%. Pada item pernyataan pola asuh otoriter, ibu menjawab sangat setuju terkait dengan memberikan teguran dengan keras pada anak $(16,4 \%)$. Lebih dari setengah ibu memberikan jawaban sangat tidak setuju pada item pernyataan pola asuh permisif terkait dengan aturan yang disesuaikan dengan kehendak anak $(51,8 \%)$.

Perilaku dibagi menjadi, total masalah perilaku, masalah emosional, masalah conduct, hiperaktif, masalah pertemanan dengan teman sebaya yang dilihat dari laporan ibu dan guru wali kelas. Penilaian perilaku ini juga melihat perilaku prososial sebagai domain kekuatan pada perilaku anak. Anak yang mengalami masalah perilaku secara keseluruhan yaitu penjumlahan total dari domain masalah emosi, masalah teman sebaya, masalah hiperaktif, masalah conduct berjumlah $47(43,7 \%)$ anak.

Masalah emosional dialami oleh 15 (13,6\%) anak. Pada domain hiperaktivitas dan conduct sebagian besar anak dalam kategori normal, yakni $103(93,6)$ anak dan terdapat $7(6,4 \%)$ yang mengalami masalah hiperaktivitas. Terlihat perbedaan interpretasi pada domain hubungan dengan teman sebaya dari laporan ibu dengan guru wali kelas. Anak yang mengalami masalah dengan teman sebaya berdasarkan laporan ibu dialami oleh $5(4,5 \%)$ anak. Namun, jika dilihat dari laporan guru wali kelas lebih banyak anak yang mengalami masalah dengan teman sebaya, yaitu 37 $(33,6 \%)$. Perilaku prososial anak terlihat hampir semua anak dalam kategori normal dan hanya $1(0,9 \%)$ anak mengalami masalah prososial.

Analisis bivariat tertera pada Tabel 2. Pola asuh Ibu menunjukkan hubungan yang signifikan dengan masalah perilaku anak secara keseluruhan dengan nilap $\mathrm{p}=0,007$ dan kekuatannya dalam kategori lemah $(\mathrm{C}=0,248)$. Anak yang memiliki masalah perilaku keseluruhan berdasarkan SDQ pada anak yang mendapatkan pola asuh non demokratis yakni sebesar $66,7 \%$. Pola asuh ibu juga memiliki hubungan yang signifikan dengan masalah conduct, dan pertemanan dengan teman sebaya. Hubungan antara variabel luar (Jenis kelamin anak, kedekatan orang tua dan anak) dengan variabel terikat (perilaku anak secara keseluruhan) tidak memiliki hubungan yang signifikan $\mathrm{p}>0,05$.

Hasil uji statistik menunjukkan bahwa terdapat hubungan yang signifikan dari pola asuh ibu dengan masalah conduct dengan nilai $\mathrm{p}=0,005$, tetapi kekuatan hubungannya dalam kategori lemah $(C=0,299)$. Pada penelitian ini terdapat hubungan yang bermakna antara pola asuh ibu dengan perilaku pertemanan dengan teman sebaya berdasarkan laporan ibu, dengan nilai $\mathrm{p}=0,000$ dan kekuatannya dalam kategori cukup $(\mathrm{C}=0,382)$.

Tabel 2. Analisis bivariat hubungan pola asuh orang tua dengan perilaku keseluruhan anak SD ( $\mathrm{n}=110)$

\begin{tabular}{lcccccccc}
\hline Variabel & \multicolumn{7}{c}{ Perilaku keseluruhan } \\
\cline { 2 - 9 } & \multicolumn{2}{c}{ Normal } & \multicolumn{2}{c}{ Abnormal } & \multicolumn{2}{c}{ Total } & C & $\mathrm{p}$ \\
\cline { 2 - 9 } & $\mathrm{f}$ & $\%$ & $\mathrm{f}$ & $\%$ & $\mathrm{f}$ & $\%$ & & \\
\hline Variabel bebas & & & & & & & & \\
$\quad$ Pola asuh ibu & 55 & 64,0 & 31 & 36,0 & 86 & 100 & 0,248 & $0,007^{*}$ \\
$\quad$ Demokratis & 8 & 33,3 & 16 & 66,7 & 24 & 100 & & \\
$\quad$ Non demokratis & & & & & & & & \\
$\quad$ Variabel luar & & & & & & & & \\
$\quad$ Jenis kelamin anak & 29 & 50,9 & 28 & 49,1 & 57 & 100 & 0,133 & 0,160 \\
$\quad$ Laki-laki & 34 & 64,9 & 19 & 35,8 & 53 & 100 & & \\
$\quad$ Perempuan & & & & & & & & \\
$\quad$ Kedekatan orang tua dan anak & 56 & 57,7 & 41 & 42,3 & 97 & 100 & 0,025 & 0,790 \\
$\quad$ Baik & 7 & 53,8 & 6 & 46,2 & 13 & 100 & & \\
$\quad$ Tidak baik &
\end{tabular}

Keterangan: $\mathrm{f}=$ frekuensi; $\mathrm{C}=$ coeffiecient contingency; $\mathrm{p}=p$ value ${ }^{*}=$ signifikan $\mathrm{p}=<0,05$ 


\section{Pembahasan}

Pola asuh ibu yang paling banyak diterapkan pada siswa SD adalah tipe pola asuh demokratis. Temuan tersebut sejalan dengan penelitian yang dilakukan Riany ${ }^{14}$ bahwa pola asuh yang ditemukan di Indonesia adalah kombinasi antara demokratis dan otoriter. Sementara di Malaysia, Koon, ${ }^{15}$ melaporkan hasil dari 200 responden, pola asuh demokratis diterapkan oleh $44,0 \%$. Pola asuh otoriter $40,5 \%$. Pola asuh permisif $10,5 \%$ orangtua dan neglectful hanya diterapkan oleh $5,0 \%$ orang tua.

Penelitian Pong, Johnston dan Chen ${ }^{16}$ melaporkan terkait pola asuh orangtua di Amerika, dibedakan antara orang tua Eropa-Amerika dan Asia- Amerika. Hasil yang didapatkan orang tua Eropa-Amerika yang menerapkan pola asuh demokrasi sebanyak 48,7\% dan otoriter sebesar 23, 1\%. Sementara orangtua AsiaAmerika menerapkan

pola asuh demokrasi $46,1 \%$ dan otoriter $25,5 \%$. Pada penelitian tersebut menjelaskan bahwa orang tua Eropa - Amerika 2\% lebih mengarah menjadi Demokrasi, sedangkan orang tua Asia - Amerika 2\% lebih mengarah otoriter. Pada penelitian tersebut juga melihat pola asuh orang tua dari sampel orang tua di Taiwan. Hasil yang dilaporkan adalah orang tua yang menerapkan pola asuh otoriter lebih tinggi dibanding dengan demokrasi, yakni otoriter (46\%) dan demokrasi $(43 \%)$.

Temuan dalam penelitian ini juga sejalan penelitian yang dilakukan oleh Trisnaningsih ${ }^{17} \mathrm{di}$ Kota Yogyakarta. Trisnaningsih melaporkan bahwa pola asuh tertinggi ibu yang diterapkan pada siswa SD adalah demokratis $(75,9 \%)$. Penerapan pola asuh demokratis terbanyak pada penelitian ini dapat dipengaruhi dari adanya kemajuan dalam teknologi sehingga orang tua lebih bersikap terbuka untuk meningkatkan pengetahuannya terhadap gaya pengasuhan yang baik untuk anaknya. Pada masa sekarang ini ibu dituntut untuk aktif berdiskusi terkait dengan perkembangan anaknya.

Pada penelitian ini terdapat 2 sekolah yang telah memfasilitasi untuk orang tua dalam seminar terkait pola asuh yang baik diterapkan untuk anak. Hal tersebut memungkinkan orangtua mengetahui bahwa pola asuh demokratis menjadi pola asuh yang baik untuk diterapkan. Sementara tingkat pendidikan terbanyak dari responden dalam penelitian ini adalah pendidikan tinggi.
Masalah perilaku keseluruhan yang terjadi sebesar $43,7 \%$ pada anak usia SD. Sekolah dasar yang digunakan pada penelitian ini berada pada kawasan perkotaan., Midouhas dan Platt ${ }^{18}$ menyebutkan bahwa perbedaan kawasan perkotaan dan pedesaan akan memengaruhi perilaku emosi anak. Domain emosional memiliki proporsi kategori abnormal yang paling tinggi dibandingkan domain lain, yakni mencapai 13,6\% anak. Temuan tersebut serupa dengan penelitian Saputra ${ }^{19}$ yakni masalah emosional muncul dengan persentase tertinggi dibandingkan dengan domain lain pada anak SD. Meskipun angka tersebut tinggi sebagai masalah perilaku, tidak terdapat hubungan antara pola asuh ibu dengan domain masalah emosional pada anak. Kemungkinan yang menyebabkan hal tersebut terjadi dapat dipengaruhi pada proses pengisian kuesioner dan adanya kemajuan teknologi. ${ }^{20}$ Salah satu perkembangan teknologi, yakni televisi, anak cenderung menghabiskan waktu yang lama untuk menonton televisi.

Proporsi kategori abnormal pada domain pertemanan dengan teman sebaya berdasarkan laporan guru wali kelas juga menunjukkan angka yang tinggi jika dibandingkan domain yang lain, yakni 37 (33,6\%). Terdapat perbedaan hasil antara laporan ibu dan guru wali kelas. Perbedaan hasil tersebut terpaut cukup jauh, yakni 33,6\% berbanding dengan 4,5\%. Beberapa penelitian memiliki hasil yang serupa dengan penelitian ini, yaitu masalah perilaku lebih tinggi jika berdasarkan laporan guru dibandingkan dengan laporan orang tua. ${ }^{21}$ Penelitian tersebut melaporkan bahwa kemungkinan hal yang menyebabkan masalah perilaku yang dilaporkan guru lebih tinggi dimungkinkan karena keadaan banyaknya siswa dalam kelas.

Berdasarkan laporan ibu terdapat hubungan antara pola asuh ibu dengan pertemanan dengan teman sebaya. Pada penelitian ini terdapat perbedaan hasil antara laporan dari ibu dan guru wali kelas. Serupa dengan penelitian Yang $\mathrm{dkk}^{22}$ di Taiwan yang melaporkan bahwa pola asuh ibu berhubungan dengan semua perilaku anak, tetapiversi guru menunjukkan tidak ada hubungan.

Hasil secara deskriptif menyebutkan terdapat 7 $(6,4 \%)$ anak yang mengalami masalah hiperaktif. Prevalensi masalah hiperaktivitas pada anak pra sekolah di Copenhagen menurut hasil penelitian yang dilaporkan oleh Elberling $\mathrm{dkk}^{23}$ adalah 5,6\%. Pada anak usia 11-17 tahun di Nepal 11,6\%. ${ }^{24}$ Anak usia pra sekolah belum banyak terpapar oleh masalah yang 
berkaitan lingkungan Semakin usia anak bertambah semakin banyak paparan terkait faktor lingkungan sekitar yang dapat menimbulkan gejala hiperaktivitas/ inatensi. Secara analisis bivariat, mendapatkan hasil bahwa tidak ada hubungan antara pola asuh ibu dengan hiperaktivitas.

Perilaku prososial merupakan aspek kekuatan pada kuesioner SDQ. Hasil penelitian secara deskriptif menunjukkan bahwa hampir semua, yakni 109 $(99,1 \%)$ anak SD memiliki perilaku prososial yang normal atau baik. Faktor-faktor yang memengaruhi perilaku prososial meliputi pola asuh orang tua dan peran keluarga sebagai model dan sumber patokan dari perilaku prososial. Teman sebaya juga berperan dalam perilaku prososial pada anak, ketersediaan kesempatan untuk berperilaku prososial maupun menerima perilaku prososial bagi anakmerupakan sumber penting feedback. ${ }^{25}$ Flouri dan Zahra ${ }^{26}$ mengemukakan bahwa rendahnya prososial yang rendah pada anak akan meningkatkan kemungkinan masalah perilaku baik eksternal maupun internal. Pada penelitian ini tingkat prososial anak hampir semua dalam kategori normal sehingga dapat menjadi kekuatan untuk menurunkan masalah perilaku pada anak. Pola asuh tidak memiliki hubungan dengan prososial, dapat disebabkan oleh jumlah antara interpretasi normal dan abnormal prososial sangat terpaut jauh.

Hasil penelitian menunjukkan bahwa terdapat hubungan antara pola asuh ibu dengan perilaku anak SD. Hasil penelitian menunjukkan bahwa persentase anak yang mendapatkan pola asuh demokratis dan memiliki perilaku normal sebesar 55 (64\%). Situmorang, Nurnaningsih, dan Sutomo ${ }^{27}$ juga melaporkan bahwa terdapat hubungan antara pola asuh orangtua dengan perilaku anak. Pada penelitian tersebut pola asuh orang tua yang lebih banyak diterapkan adalah non demokratis. Perbedaan dengan penelitian ini adalah terkait sampel yang digunakan, yakni ibu yang memiliki anak pra sekolah, dilakukan di Kota Yogyakarta, serta menggunakan kuesioner pola asuh yang berbeda. Beberapa hal tersebut menjadi kemungkinan berbedanya jumlah pola asuh yang diterapkan dengan penelitian ini. Kawabata $\mathrm{dkk}{ }^{28}$ menyimpulkan bahwa pola asuh yang positif, dikarakteristikkan dengan kehangatan orang tua dan sensitifitas orang tua.

Pola asuh otoriter ini memiliki ciri, seperti kaku, tegas, suka menghukum, kurang ada kasih sayang, serta tidak simpatik. Orang tua di sini memaksa anak untuk patuh terhadap yang diyakini oleh orang tua. Orang tua memegang kekuasaan tertinggi juga mengharuskan anak patuh pada perintahnya. Kontrol pada orang tua sangat ketat. Pola asuh otoriter ini memberikan efek negatif pada kesehatan mental anak. ${ }^{29}$

Pola asuh permisif cenderung memberikan kebebasan kepada anak, orang tua juga memberikan kontrol yang longar kepada anak. Anak dalam keluarga permisif ini cenderung sedikit sekali dalam tuntutan tanggung jawab oleh orang tua, tetapi memiliki hak yang sama dengan orang dewasa. Orang tua permisif ini menentukan aturannya sesuai dengan kemauan anak. Anak diberikan kebebasan untuk mengatur dirinya sendiri. Pola asuh permisif akan memberikan dampak terhadap terjadinya masalah perilaku eksternalisasi pada anak. ${ }^{30}$

Variabel jenis kelamin tidak menunjukkan hubungan dengan perilaku keseluruhan. Serupa dengan penelitian Saputra $\mathrm{dkk}^{19}$ yang melaporkan bahwa gender tidak berhubungan dengan perilaku anak yang diukur dengan SDQ.

Kedekatan orang tua dan anak secara deskriptif menunjukkan bahwa responden memiliki kedekatan yang tidak baik. Hasil penelitian Al- Qaisy ${ }^{31}$ melaporkan bahwa hubungan keluarga yang memiliki kohesi yang tinggi dan konflik yang sedikit maka anak tidak mengalami masalah perilaku. Namun sebaliknya, apabila keluarga dengan kohesi yang rendah dan konflik yang tinggi maka anak akan mengalami masalah perilaku. Kedekatan orang tua dan anak tidak berhubungan dengan dengan perilaku anak pada penelitian ini. Hasil penelitian ini sesuai dengan penelitian Ferreira dkk ${ }^{32}$ yang melaporkan bahwa kedekatan ibu dan anak tidak berhubungan terhadap perilaku anak. Sementara kedekatan ayah dan anak serta guru dan anak memiliki hubungan dengan perilaku anak.

Penelitian ini menggunakan teknik pengambilan sampel dengan metode multi stage cluster random sampling, dengan jumlah sampel minimal 110 . Penggunaan teknik sampling tersebut menjadi kekuatan dalam penelitian ini. Hasil pada penelitian ini dapat menjadi pertimbangan untuk kebijakan dari dinas pendidikan dan sekolah dalam memperhatikan terkait skrining perilaku anak, perkembangan anak, dan segera memberikan intervensi apabila terdapat masalah perkembangan anak sehingga dapat bekerjasama dengan tenaga kesehatan anak. Penelitian ini telah menggunakan kuesioner perilaku yang 
standar, yakni SDQ yang telah digunakan di banyak negara. Berdasarkan hasil penelitian ini juga menjadi data bagi pihak dinas pendidikan, sekolah, maupun tenaga kesehatan untuk melakukan pencegahan masalah perilaku anak, serta mengoptimalkan perilaku prososial anak yang sudah baik.

\section{Kesimpulan}

Pola asuh demokratis diterapkan oleh ibu sebanyak $78,2 \%$, pola asuh otoriter $19,1 \%$, dan pola asuh permisif hanya diterapkan $2,7 \%$. Masalah perilaku pada anak SD sebanyak 43, 7\%. Persentase masalah emosional terjadi pada anak SD sebesar 13, 6\%. Persentase masalah pertemanan dengan teman sebaya mencapai 33,6\%. Terdapat hubungan antara pola asuh ibu dengan masalah perilaku anak secara keseluruhan pada anak SD. Tidak terdapat hubungan antara jenis kelamin anak, dan kedekatan orangtua dan anak dengan perilaku anak.

\section{Daftar pustaka}

1. Broidy LM, Nagin DS, Tremblay RE. Developmental trajectories of childhood disruptive behaviors and adolescent delinquency: a six-site, cross-national study. Dev Psychol 2003;39:222-45.

2. Braza P, Careras R, Munoz JM, Braza F, Azurmendi, A, Pascual-Sagastiza E, dkk. Negative maternal and paternal parenting styles as predictors of children's behavioral problems: moderating effects of the child's sex. J Child Fam Study 2013;24:847-856.

3. LaGasse L L, Elisabeth C, Sarah KL. Transactional relations between caregiving stress, executive functioning, and problem behavior from early childhood to early adolescence. Dev Psychopatol 2016.doi:10.1017/S0954579416000286.

4. Oktaviani M, Wimbarti S. Validasi klinik strenghts and difficulties questionnaire (SDQ) sebagai instrumen skrining gangguan tingkah laku. Jurnal Psikologi 2014;41:101-114.

5. Yusuf S. Psikologi perkembangan anak dan remaja, Bandung: Rosdakarya; 2015.

6. Van der Gesst KE, Merele SYM, Rodenburg G. Cross-sectional associations between maternal parenting styles, physical activity and screen sedentary time in children. BMC Pub Health 2017. doi 10.1186/s12889-017-4784-8.

7. Hoeve M, Judith SD, Veroni IE. The relationship between parenting and delinquency: A Meta-analysis. J Abn Child
Psychol 2009;37:749-75. doi: 10.1007/s10802-009-9310-8.

8. Carey WB, Crocker AC, Coleman WL. DevelopmentalBehavioral Pediatrics. Edisi ke-4. Phinadelphia: Saunder Elsevier; 2009.

9. Pujianingsih ET. Hubungan pola asuh orang tua dengan gangguan emosi dan perilaku remaja SMP pasca erupsi Merapi di Kecamatan Cangkringan, skripsi. Yogyakarta: UGM, 2015.

10. Murdhati RD. Pola asuh orang tua pada anak dengan gangguan pemusatan perhatian, tesis. Yogyakarta: Fakultas Ilmu Kedokteran Klinis UGM. (Unpublished), 2009..

11. Goodman R. Psychometric properties of the strength and difficulties questionnaire (SDQ). J Am Acad Child Adolesc Psychiaty 2001;40:1337-45.

12. Fok CCT, James A, David H. The brief family relationship scale: a brief measure of the relationship dimension in family functioning; assesment. PMC 2014;21:67-72.

13. Murti B. Desain dan ukuran sampel untuk penelitian kuantitatif dan kualitatif di bidang kesehatan. Yogyakarta: Gadjah Mada University Press; 2006.

14. Riany YE, Pamela M, Monica C. Understanding the influence of traditional cultural values on Indonesian parenting. Marriage \& Family Review 2017;53:20726. doi: 10.1080/01494929.2016.1157561.

15. Koon WL. The relationship between parenting style and factor of demand on private tutoring in Klang Valey, Malaysia. Thesis. 2014. Diakses pada tanggal 9 Oktober 2018. Didapat dari: eprints.utar.edu.my.

16. Pong S, Jamie J, Vivien C. Authoritarian Parenting and Asian Adolescent School. Int J Behav Dev 2010; 34:62-72.

17. Trisnaningsih. Hubungan pola asuh dengan derajat depresi pada siswa sekolah dasar negri di Kota Yogyakarta, skripsi. 2011. Diakses pada 20 Februari 2020. Didapat dari: $w w w$. ugm.ac.id.

18. Midouhas, Emily, Platt. Rural-urban area of residence and trajectories of children's behaviour in England. Health and Place 2014;30:226-233.

19. Saputra F, Yunibhand J, Sukratul S. Relationship between personal, maternal, and familial factors with mental health problems in school-aged children in Aceh Province Indonesia, Asian J Psychiatry 2016; 25:207-12.

20. Farrel $\mathrm{G}$. The relationship between parenting style and then level of emotional intelligence in preschool-aged children.. Diakses pada 20 Februari 2020. Didapat dari: https://digitalcommons. pcom.edu/cgi/viewcontent.cgi article $=1340$ scontext $=$ psycholo gy_dissertations.

21. Elhammid AA, Amanda H, Richard R. Prevalence of emotional and behavioural problems among 6-12 year old children in Egypt. Soc Psychiatr Epidemiol 2009;44:8-14.

22. Yang HJ, Kuo YJ, Wang L, Yang CY. Culture, parenting, 
and child behavioral problems: a comparative study of crosscultural immigrant families and native-born families in Taiwan. Transcultural Psychiatry 2014;51:526-44.

23. Elberling H, Linneberg A, Olsen EM, Goodman R, Skovgaard AM. The prevalence of SDQ-measured mental health problems at age 5-7 years and identification of predictors from birth to preschool age in a Danish birth cohort: The Copenhagen Child Cohort 2000. Eur Child Adolesc Psychiatr 2010;19:725-35.

24. Rimal HS, Archana P. Assessment of mental health problems of school children aged 11-17 years using self report strength and difficulty questionnaire (SDQ). J Nepal Paediatr Soc 2013;33:172-6.

25. Chin-Hung CV, Chin-Jung Y, Tzu- Chi L, Jen-Yu C, WenChuan S, Ding-Ho S, dkk. Symptoms of attention deficit hyperactiv ity disorder and quality of life of mothers of schoolaged children: The roles of child, mother, and family variables. Kaohsiung J Med Sci 2014;30:631-8.

26. Flouri E, Zahra S. Procial behavior and childhood trajectories of internalizing and externalizing problems: the role of neighborhood and school contexts. Developmental Psychol 2016;52:253-8.
27. Situmorang TSK, Nurnaningsih, Sutomo R. Perbedaan perilaku anak prasekolah berdasarkan pola pengasuhan. Sari Pediatri 2016;18:314-9

28. Kawabata Y, Alink LRA, Tseng W. Maternal and paternal parenting styles associated with relational aggression in children and adolescents: A conceptual analysis and metaanalytic review. Dev Rev 2011;31:240-27.

29. Uji M, Ayuko S, Keiichiro A. The impact of authoritative, authoritarian, and permissive parenting styles on children's later mental health in Japan: focusing on parent and child gender. J Child Fam Stud 2014;23:293-302.

30. Rosli NA. Effect of parenting styles on children's emotional and behavioral problems among different ethnicities of muslim children in the U.S. 2014, disertation. Diakses pada 20 Februari 2020. Didapat dari: http://epublications. marquette. eduldissertations_mu/376.

31. Al- Qaisy LM. Family relationship of children with behavior disorders. Int J Learn Dev 2011;1:1-13.

32. Ferreira T, Joana C, Marisa M, Joana MV, Teresa L, Matos PM. Preschool children's prosocial behavior: the role of motherchild, father-child and teacher-child relationships. J Child Fam Stud 2016;25:1829-39. 